\title{
Potential Gains to New Zealand From CPTPP Membership
}

\author{
Satya Gonuguntla ${ }^{1}$ \\ ${ }^{1}$ School of Business, Manukau Institute of Technology, Auckland, New Zealand \\ Correspondence: Dr. Satya Gonuguntla, School of Business, Manukau Institute of Technology, 25, Davies \\ Avenue, Manukau City, Auckland 2241, New Zealand.
}

Received: June 21, 2019

Accepted: July 29, 2019

Online Published: August 2, 2019

doi:10.20849/abr.v4i2.617

URL: https://doi.org/10.20849/abr.v4i2.617

\begin{abstract}
New Zealand is a signatory to the Comprehensive and Progressive Agreement for Trans-Pacific Partnership (CPTPP) consisting of 11 countries. NZ does not have any bilateral trade agreement with three member countries viz., Canada, Japan, and Mexico which account for 73\% of CPTPP's GDP. Presently, NZ accounts for less than $1 \%$ of the merchandise imports of these countries. This paper investigates whether CPTPP membership would enable NZ to increase its exports to these member countries. In other words, does CPTPP membership enhance NZ's Trade Intensity with the selected member countries? An analysis of the Trade Intensity Indices show that the value of trade with Canada, and Mexico is less than optimal, and with Japan it has been on the decline which can be attributed to the fact that these countries mostly import high value added goods such as capital goods whereas, NZ mostly exports primary goods such as animals. A further analysis of NZ's Revealed Comparative Advantage reveals that NZ's comparative advantage is mostly concentrated in primary products. As a consequence, the scope for NZ to enhance its exports to the selected member countries is limited in the post CPTPP era, and any gains arising out of the agreement would be mostly in the form of tariff reductions, and relaxation of non-tariff barriers. The contribution of this paper is about highlighting NZ's product-wise Revealed Comparative Advantage in relation to the selected member countries, which reveals that NZ has the potential to export Intermediate and Consumer goods, in addition to the Primary goods.
\end{abstract}

Keywords: New Zealand, CPTPP, trade intensity, revealed comparative advantage, primary products

JEL Classification: F140, F150.

\section{Introduction}

The proposed Comprehensive and Progressive Agreement for Trans-Pacific Partnership (CPTPP) is a free trade agreement among 11 countries viz., New Zealand (NZ), Australia, Singapore, Japan, Malaysia, Brunei Darussalam, Canada, Mexico, Peru, Chile, and Viet Nam. The CPTPP has been negotiated by these countries to replace the Trans-Pacific Partnership Agreement (TPP). The TPP involved in all 12 countries i.e. the 11 CPTPP countries plus the US. However, the US withdrew from the negotiations, and the remaining 11 countries re-named the agreement and concluded the negotiations in January 2018. The agreement came into force in December, 2018. The 11 member countries account for $13 \%$ of world GDP, and $30 \%$ of New Zealand's merchandise exports, and 65\% of FDI into NZ (MFAT, 2018). Given the small domestic market size with a population of 4.9 million, external trade which accounts for $53 \%$ of GDP, is crucial for the economic prosperity of NZ (The World Bank, 2017). As part of its multi-pronged trade policy, NZ has negotiated several bilateral, and regional Free Trade Agreements (FTAs) in order to create opportunities for New Zealand exporters in overseas markets. Some key bilateral FTAs include the Closer Economic Relations agreement with Australia (1983), PRC (2008), and Malaysia (2010). In addition NZ is also a signatory to FTAs with regional trade blocks such as ASEAN. NZ is also a founding member of the Asia-Pacific Economic Co-operation (APEC) which aims to promote free trade among the member countries. FTAs that are under negotiation include EU-NZ FTA, and Regional Comprehensive Economic Partnership (RCEP) consisting of ASEAN members plus six countries with which ASEAN has FTAs, the two key objectives being reduction in tariff and non-tariff barriers and better market access to NZ exporters. It may be noted that although NZ trades with several countries, two countries viz., Australia, and PRC account for $40 \%$ merchandise exports. Since the external trade is concentrated in few markets which is not very ideal, NZ needs to diversify into new markets in order to sustain its trade based prosperity. 
The aim of this paper is to analyse the Trade Intensities with selected CPTPP member countries i.e. Japan, Mexico, and Canada which account for 73\% CPTPP's GDP. In terms of export destination rankings, Japan is fifth largest export destination for NZ's merchandise exports followed by Canada (16), and Mexico (23). However, NZ does not have bilateral FTAs with any of these countries. This paper investigates whether the extent of current trade intensities between NZ and the selected countries are optimum, and whether NZ has comparative advantage in relation to the major merchandise imports of these countries i.e. NZ's potential to increase its exports to these countries. The rest of the paper is organized as follows: Literature Review is presented in Section 2, Section 3 outlines the Methodology followed by Analysis and Discussion in Section 4, and Section 5 consists of the Conclusions.

\section{Literature Review}

Free Trade Agreements (FTAs) are negotiated in order to gain access to new markets, remove or liberalise tariff, and non- tariff barriers, with the ultimate aim of enhancing the trade flows among the member countries. As a consequence of lack of progress in WTO negotiations, many countries opted for bilateral, regional and multi-lateral FTAs as an alternative to a comprehensive trade agreement at global level. The number of Regional Trade Agreements (RTAs) increased from 79 in the year 2000 to 291 by 2018 (WTO, 2019). In line with the global trend, the countries in the Asia-Pacific region negotiated several RTAs to take advantage of the benefits associated with free trade e.g. New Zealand is a signatory to 12 RTAs, and Australia is a signatory to 13 RTAs at the end of 2018 (WTO, 2019). FTAs are considered to be the second-best option compared to the cumbersome WTO agreements. Desker (2004), argued that during the 90s, there has been a shift in East Asia from a focus on multilateral trade liberalisation through the WTO to a pragmatic approach favouring bilateral and regional FTAs while continuing to support the WTO system. Every FTA aims to achieve certain specific objectives that are beneficial to the member countries such as free access to export markets. Wilson (2012), identified three motives as the drivers of FTAs in the Asia-Pacific region viz., trade liberalisation, preferential access to key export markets, and/or the use of FTAs for political gains. For example, the main objectives of NZ- China FTA include, encourage expansion and diversification of trade, and eliminate barriers to trade in, and facilitate the cross-border movement of, goods and services between the two countries. There is evidence that NZ has achieved the objective of trade expansion with PRC in that by 2013 the latter replaced Australia as the top most trading partner of NZ.

FTAs not only promote trade in manufactured goods but also increase the trade flows in agricultural products. A study of the impact of free trade agreements on agricultural trade flows in general and dairy, vegetable, live animals, meat and sugar in particular, among selected North African countries (Algeria, Egypt, Morocco and Tunisia) found that being a member of trade agreement is not only positively associated with aggregate agricultural trade flow but also potential for trade creation. The study estimated that trade agreement could increase agricultural trade flow by around 39 percent in trade volume (Hndi et al., 2016).

It is quite likely the benefits of an FTA may not be evenly enjoyed by the trading partners i.e. one member may gain more than the other member in a bilateral FTA due to certain inherent advantages. A study of the impact of the Thailand-Australia Free Trade Agreement (TAFTA) found a significant positive impact of the TAFTA only on Australian exports to Thailand, but not vice-versa (Siddique and Sriatsava, 2015). This should not imply that countries with implicit uneven distribution of resources should not negotiate FTAs as the benefits associated with FTAs exceed any disadvantages. As an example, ASEAN consists of developed countries such as Singapore, and developing countries such as Myanmar. The benefits arising out of economic integration and free trade accrue to both these member economics albeit to different degrees. Given the positive influence of such economic and trade integration measures non-ASEAN members are negotiating an FTA with ASEAN to make it ASEAN+6. Suvannaphakdy and Toyoda (2014) found that the expansion of ASEAN into ASEAN +3 and ASEAN +6 is important for promoting its members' exports through the elimination of tariff barriers, and forming an economic community with ASEAN i.e. ASEAN +6 will help promote trade between these countries via the overall promotion of intraregional trade. Das et al., 2016), in their study of ASEAN+6 FTA found that FTAs enhance the link between trade and FDI, promote Intra Industry Trade through horizontal and vertical integration, technological improvements, and product differentiation that facilitate regional value chains. Their empirical analysis concluded that a comprehensive FTA in goods among the ASEAN+6 countries under the Regional Comprehensive Economic Partnership results in enhanced trade flows among the member countries. Kawai and Nakoni (2017), also support the view that the FTA negotiations with non-ASEAN members such as India and forming a RCEP, will increase trade as well as FDI inflows benefiting the emerging economies. In order to maximize the benefits of trade, apart from the FTAs, the role of proper infrastructure connecting the member countries is crucial. Physical connectivity in the form of transportation, communication, and modern 
banking facilities are essential to enjoy the benefits of free trade (Chia, 2016). Given the gains arising from FTAs, both bilateral and regional, there is scope for NZ to enhance merchandise exports to the selected member countries in the post CPTPP era.

\section{Methodology}

Trade Intensity Indices are computed to assess the extent of trade between NZ and the selected member countries i.e. whether the value of trade is above or below the expected threshold. This is followed by an analysis of NZ's Revealed Comparative Advantage to examine NZ's ability to enhance exports as a result of CPTPP.

The trade intensity index is used to determine whether the value of trade between two countries is greater or smaller than would be expected on the basis of their importance in world trade (WITS, 2019). We can think of the trade intensity index as a uniform export share. The index reveals whether or not a country exports more (as a percentage) to a given destination than the world does on average. An advantage of this measure is that it does not suffer from any 'size' bias, so a comparison can be made across regions, and over a period of time. Trade Intensity Index $\left(\mathrm{I}_{\mathrm{ij}}\right)$ for country i's exports to country $\mathrm{j}$ is defined as the share of county $\mathrm{j}$ in country $\mathrm{i}$ 's total exports $\left(X_{i j} / X_{i}\right)$ relative to the share of $j$ 's imports $\left(M_{j}\right)$ in total world imports, net of i's imports $\left(M_{w}-M_{i}\right)$.

$$
\mathrm{I}_{\mathrm{ij}}=\left(\mathrm{X}_{\mathrm{ij}} / \mathrm{X}_{\mathrm{i}}\right) /\left(\mathrm{M}_{\mathrm{j}} /\left(\mathrm{M}_{\mathrm{w}}-\mathrm{M}_{\mathrm{i}}\right)\right)
$$

The term $\mathrm{M}_{\mathrm{i}}$ is deducted from the denominator to take into account that a country does not import to or export from itself. A value of the index greater than unity indicates that country $i$ trades with country $j$ more intensely than does the world as a whole. A value of less than unity indicates a small flow of trade between $i$ and $j$ relative to j's trade with the rest of the world (Braga, 1994; Faezeh, 1998).

Revealed Comparative Advantage (RCA) reveals the extent of a country's revealed comparative advantage in regards to a particular industry on the basis of the industry's export performance. RCA indices also indicate a country's potential to trade with other countries. Trade flows between countries with similar RCA indices tend to be lower than those with dissimilar indices.

The RCA index of country i for product $j$ is often measured by the product's share in the country's exports in relation to its share in world trade:

$$
\operatorname{RCA}_{\mathrm{ij}}=\left(\mathrm{x}_{\mathrm{ij}} / \mathrm{X}_{\mathrm{it}}\right) /\left(\mathrm{x}_{\mathrm{wj}} / \mathrm{X}_{\mathrm{wt}}\right)
$$

Where $x_{i j}$ and $x_{w j}$ are the values of country i's exports of product $j$ and world exports of product $j$ and where $X_{i t}$ and $X_{w t}$ refer to the country's total exports and world total exports. A value of less than unity implies that the country has a revealed comparative disadvantage in the product. Similarly, if the index exceeds unity, the country is said to have a revealed comparative advantage in the product (WITS).

\section{Analysis and Discussion}

In terms of trade with Japan, the trade intensity indices have been consistently higher than 1 indicating that NZ trades with Japan more intensely i.e. the value of merchandise exports from New Zealand to Japan is higher than what would be expected based on New Zealand's importance in the world trade (Table-1). However, there has been a decline in the index from 2.11 in 2001 to 1.41 by 2017 indicating a gradual decline in NZ's share in Japan's imports. A related variable is NZ's share in the merchandise imports of the selected countries. NZ accounts for less than $1 \%$ of Japan's total merchandise imports, which has also decreased from $0.59 \%$ in 20001 to $0.37 \%$ in 2017 (Table-2) consistent with the declining trade intensity indices. Similar trends can be observed in the case of trade with Canada, and Mexico. The trade intensity indices have been less than 1 indicating the low value of exports from NZ to these two countries (Table-1). Even the share of merchandise imports from NZ is less than $1 \%$ which has been declining over the years (Table-2). Overall, it is clear that the value of NZ's exports to Canada, Japan, and Mexico have been on the decline. Going by the terms of the Trade Intensity Index formula, the most probable cause for this decline could be due to the differences in the nature of the merchandise goods that are imported by the member countries and what NZ is capable of exporting based on its resources. 
Table 1. NZ's trade intensities with Canada, Japan, and Mexico

\begin{tabular}{llll}
\hline Year & Canada & Japan & Mexico \\
\hline 2001 & 0.52 & 2.11 & 0.59 \\
\hline 2002 & 0.59 & 2.10 & 0.56 \\
\hline 2003 & 0.59 & 2.06 & 0.63 \\
\hline 2004 & 0.56 & 2.16 & 0.59 \\
\hline 2005 & 0.55 & 2.03 & 0.65 \\
\hline 2006 & 0.55 & 1.48 & 0.41 \\
\hline 2007 & 0.39 & 1.46 & 0.59 \\
\hline 2008 & 0.39 & 1.28 & 0.39 \\
\hline 2009 & 0.35 & 1.14 & 0.37 \\
\hline 2010 & 0.36 & 1.19 & 0.30 \\
\hline 2011 & 0.32 & 1.44 & 0.44 \\
\hline 2012 & 0.49 & 1.31 & 0.28 \\
\hline 2013 & 0.45 & 1.14 & 0.27 \\
\hline 2014 & 0.39 & 1.26 & 0.25 \\
\hline 2015 & 0.45 & 1.48 & 0.30 \\
\hline 2016 & 0.50 & 1.41 & 0.37 \\
\hline 2017 & 0.46 & 1.41 & 0.27 \\
\hline
\end{tabular}

Source: Own calculations based on data from UN COMTRADE, and WITS

Table 2. Merchandise imports from NZ (\%)

\begin{tabular}{llcc}
\hline Year & Canada & Japan & Mexico \\
\hline 2001 & 0.15 & 0.59 & 0.15 \\
\hline 2005 & 0.15 & 0.49 & 0.17 \\
\hline 2010 & 0.11 & 0.39 & 0.12 \\
\hline 2015 & 0.13 & 0.38 & 0.09 \\
\hline 2017 & 0.13 & 0.37 & 0.09 \\
\hline
\end{tabular}

Source: WITS, World Bank.

Table 3. Top merchandise imports (2017)

Imports from Rest of the World (\% total imports)

\begin{tabular}{llll}
\hline Goods/Country & Canada & Japan & Mexico \\
\hline Capital goods & $36 \%$ & $27 \%$ & $45 \%$ \\
\hline Consumer goods & $36 \%$ & $33 \%$ & $28 \%$ \\
\hline Transportation & $20 \%$ & $4 \%$ & $10 \%$ \\
\hline Intermediate goods & $17 \%$ & $15 \%$ & $19 \%$ \\
\hline $\begin{array}{l}\text { Machinery \& Electrical } \\
\text { Equipment }\end{array}$ & $25 \%$ & $24 \%$ & $37 \%$ \\
\hline Vegetables & & & $2.85 \%$ \\
\hline Wood & $3.0 \%$ & $3.1 \%$ & $2.14 \%$ \\
\hline
\end{tabular}

Source: WITS, World Bank. 
Table 4. Imports from New Zealand

(\% total imports from NZ)

\begin{tabular}{llll}
\hline Product/Country & Canada & Japan & Mexico \\
\hline Animal & $45 \%$ & $29 \%$ & $63 \%$ \\
\hline Chemicals & $8 \%$ & $9 \%$ & $20 \%$ \\
\hline Food products & $21 \%$ & $9 \%$ & $1 \%$ \\
\hline Machinery\&Electrical Equipment & $12 \%$ & $0.90 \%$ & $7 \%$ \\
\hline Metals & $0.60 \%$ & $16 \%$ & $0.40 \%$ \\
\hline Vegetables & & & $1.70 \%$ \\
\hline Wood & $6 \%$ & $17 \%$ & $0.30 \%$ \\
\hline
\end{tabular}

Source: WITS, World Bank.

A comparison of the type of the merchandise goods that the member countries mostly import from the rest of the world, and the goods they mostly import from NZ reveals a significant mismatch between the two. A significant percentage of imports by the member countries consist of non-primary goods i.e. about $90 \%$ of imports by these countries consist of high value added, processed goods such as capital goods, consumer goods, and Machinery and Electrical Equipment (Table-3). It may be observed that NZ's exports do not figure in any of the top imports of the member countries (Table-4). On average primary products, such as Animals, account for $75 \%$ of NZ's exports to Canada, Japan, and Mexico. The falling NZ's share of exports to these countries can be attributed to the divergence in the nature of goods that these countries predominantly import from the world and what NZ predominantly exports. Given this kind of contrast, and current insignificant share of NZ's exports to these member countries, whether CPTPP is going to improve NZ's trade intensities or is going to be beneficial to NZ in other ways needs to be examined. NZ should be capable of exporting the goods that the member countries mostly import in order to gain significantly from the CPTPP. In other words, NZ needs diversify from primary to high value added products. In order to achieve this, NZ has to have comparative advantage in the products which the member countries mostly import from rest of the world. Revealed Comparative Advantage Indices are used to assess a country's export potential and trade prospects in new markets (WITS).

Table 5. NZ's RCA index numbers-2017

\begin{tabular}{llll}
\hline Goods type/Country & Canada & Japan & Mexico \\
\hline Capital goods & 0.41 & 0.08 & 0.19 \\
\hline Consumer goods & 0.90 & 0.65 & 2.04 \\
\hline Transportation & 0.05 & 0.02 & 0.00 \\
\hline Intermediate goods & 0.67 & 2.46 & 1.19 \\
\hline Animal & 38.3 & 8.2 & 38.5 \\
\hline Wood & 0.22 & 5.8 & 0.15 \\
\hline Metals & 0.09 & 3.34 & 0.05 \\
\hline Mach \& Elec & 0.48 & 0.04 & 0.20 \\
\hline Chemicals & 0.91 & 1.07 & 2.81 \\
\hline Vegetables & 2.08 & 5.57 & 0.58 \\
\hline Food products & 4.73 & 2.33 & 0.52 \\
\hline
\end{tabular}

Source: WITS, World Bank. 
The RCA indices indicate that NZ has comparative advantage mostly in primary products (Table-5). NZ's RCA is significant in Animal, Wood, and Vegetables i.e. all primary products. Whereas in the case of Capital goods, and Transportation the value of RCA indices is less than unity consistent with the fact that NZ is endowed with more of natural resources rather than with resources such as highly skilled labour, and technology required to produce high value added goods. However, the RCA indices indicate that there is potential for NZ to increase the exports of Consumer goods to Mexico, Intermediate goods to Japan, and Mexico. Also there is potential to increase the exports of Chemicals to all the three markets.

The significant benefit that could accrue to NZ out of CPTPP from the three member countries would be in the form of reduced tariffs on the primary products that $\mathrm{NZ}$ is currently exporting. Animal is a major export item to all the three markets which is subject to varying tariff rates i.e. Mexico 13\%, Japan 26\%, and Canada $34 \%$.

\section{Conclusions}

NZ being a small country isolated from larger markets, depends on trade to achieve economic prosperity. In order to gain access to large markets, NZ has been a signatory to several bilateral, and regional trade agreements such the ANZCER with Australia, and the FTA with PRC. The evidence shows that trade has increased considerably with these countries post FTA years. Encouraged by the outcome of such FTAs, NZ has joined the CPTPP to gain the potential benefits associated with such a multi-lateral trade agreement. In order to realise the benefits from this broad Free Trade Agreement, NZ must be capable of exporting goods that are mostly imported by the member countries. This study analysed current trade position, and NZ's export potential of various categories of merchandise goods to the selected member countries. Three member countries viz., Canada, Japan, and Mexico which are relatively large in size with which NZ does not have a bilateral trade agreement have been selected. An analysis of the current magnitude of trade in terms of trade intensities between NZ and the selected member countries reveals that except with Japan, the intensity of trade has been less than unity. This indicates that NZ's exports to Canada, and Mexico are less than the expected value in relation to NZ's position in world trade. However, a Trade Intensity Index of greater than unity with Japan reveals that the actual value of NZ's exports exceeds the expected threshold.

An examination of trade data shows that in absolute terms, $\mathrm{NZ}$ accounts for less than $1 \%$ total merchandise imports of each of the three countries. The reason for this insignificant share is that the member countries mostly import high value added goods such as Capital goods, whereas NZ mostly exports primary products such as Animal. In order for NZ to make any significant gains from CPTPP, it is essential that NZ diversifies from primary to high value added goods such as Capital goods. An analysis of NZ's Revealed Comparative Advantage shows that NZ has comparative advantage predominantly in primary products such as Animal with the member countries. However, the primary products account for a small percent of the member countries' overall imports. The possibility of NZ improving its comparative advantage with regard to Capital goods appears to be remote. There is scope to increase the exports of Consumer goods to Mexico, and Intermediate goods to Mexico and Japan as the RCA index for these products exceeds unity.

Another significant gain to NZ would be in the form of tariff reductions by the CPTPP member countries. The Ministry of Foreign Affairs and Trade estimates that the NZ exporters will be able to save up to $\$ 220$ million per annum on dairy, beef, forestry exports to the CPTPP members. In addition, several Non-Tariff Barriers such as compliance costs would be reduced in the post-CPTPP era. Overall, the potential gains to NZ arising of CPTPP to the selected member countries would be limited to tariff reductions rather than gains associated with diversification due to NZ's comparative advantage being concentrated mostly in primary products. Bilateral FTAs with these countries may help NZ to expand the current exports as happened in the case of Australia and PRC.

\section{References}

Braga, C.A.P., Safadi, R., \& Yeats, A. (1994). Regional integration in the Americas: De ja vu all over again?. World Economy, 17(4), 571-601.

Chia, S.Y. (2016). ASEAN Economic Integration and Physical Connectivity. Asian Economic Papers, 15(2). https://doi.org/10.1162/ASEP_a_00438

Das, R.U., Rishi, M., \& Dubey, J.D. (2016). Asean Plus Six and Successful FTAS: Can India Propel Intra-Industry Trade Flows?. The Journal of Developing Areas, 50(2).

Desker, B. (2004). In defence of FTAs: from purity to pragmatism in East Asia. The Pacific Review, 17(1). https://doi.org/10.1080/0951274042000182393

Faezeh, F. (1998). Does Membership in a Regional Preferential Trade Arrangement Make A Country More or Less Protectionist?. World Economy, 21(3). 
Hndi, B. M., Maitah, M., \& Mustofa, J. (2016). Trade Impacts of Selected Free Trade Agreements on Agriculture: The Case of Selected North African Countries. Agris On-line Papers in Economics and Informatics, VIII(3).

Kawai, M., \& Naknoi, K. (2017). ASEAN's Trade and Foreign Direct Investment: Long-Term Challenges for Economic Integration. The Singapore Economic Review, 62(3), 643-680 https://doi.org/10.1142/S0217590818400040

Siddique, M.A.B., \& Srivastava, R.S.S. (2016). Australia-Thailand Trade: An Analysis of Competitiveness and Effects of the Bilateral FTA. The Journal of Developing Areas, 50(5).

Suvannaphakdy, S., \& Toyoda, T. (2014). Impact of Regional Trade Agreements in East Asia on Members' Trade Flows. Journal of Southeast Asian Economies, 31(3), 361-78.

Wilson, J.D. (2012). Resource security: a new motivation for free trade agreements in the Asia-Pacific region. The Pacific Review, 25(4). https://doi.org/10.1080/09512748.2012.685098

\section{Websites}

Retrieved 7th February, 2019, from https://data.worldbank.org/indicator/NE.TRD.GNFS.ZS?locations=NZ

$\begin{array}{llll}\text { Retrieved } & \text { Fth } & \text { February, } & \text { 2019, from }\end{array}$ https:/www.wto.org/search/search_e.aspx?search=basic\&searchText=FTAs\&method=pagination\&pag=0\& roles $=\% 2$ Cpublic $\% 2 \mathrm{C}$

$\begin{array}{llll}\text { Retrieved } & \text { February, } & \text { 2019, from }\end{array}$ https://wits.worldbank.org/wits/wits/witshelp/Content/Utilities/e1.trade_indicators.htm

Retrieved 11th March, 2019, from https://www.mfat.govt.nz viewed

\section{Copyrights}

Copyright for this article is retained by the author(s), with first publication rights granted to the journal.

This is an open-access article distributed under the terms and conditions of the Creative Commons Attribution license (http://creativecommons.org/licenses/by/4.0/). 